\title{
The Significance and Symbolism of Grifon in Ancient Egypt till the Greco- Roman Periods
}

\section{The Significance and Symbolism of Grifon in Ancient Egypt till the Greco-Roman Periods}

\author{
Ahmed Mashhot Ahmed keshka \\ Department of Egyptology - Faculty of Archaeology- Fayoum University \\ amk05@fayoum.edu.eg
}

\begin{abstract}
This study focuses and examines the ancient Egyptian iconography and texts of the mythological creature known as Grifon, Griffin, Griffon and Gryphon, from the earliest times till the Greco-Roman periods. This study will shed light on its religious iconography and its distinctive relationship with some other gods such as; Re and Horus Behdety with a falcon head and its relationship with the Ka of the King. The frequent manifestations of the Grifon provide three main forms which may distinguish as follows; the Sphinx with a human head, a winged lion with a falcon head, and a winged lion with a human head, which also includes the female sphinx winged. The Grifon or the so-called Gryphon was one of the oldest and most composite and mixed or hybrid animals in the civilizations of ancient Egypt and ancient Near East. There were many forms and various characteristics of the Grifon which emerged in many texts and scenes. Sometimes it was violent and predator, and occasionally was devoted to protecting, which was regarded as profoundly immoral and wicked, or divine and as a god. There were many forms of myths about the Grifon, as there were several forms and varied for it. This study will highlight the significance and symbolism of the Grifon in ancient Egypt until the Greco-Roman Periods. The methodology of this study will be addressed through discussion of the notable aspects of the extent of effect of Grifon creature through texts and scenes.
\end{abstract}

Keywords: Grifon, Significance and Symbolism, Ancient Egypt and GrecoRoman Periods, Iconography, Ka of the King

\section{Introduction:}

The Grifon or the so-called Gryphon was one of the oldest and most composite and mixed or hybrid animals in the civilizations of ancient Egypt and ancient Near East. There were many forms and various characteristics of the Grifon, which emerged in many texts and scenes. Sometimes it was violent and predator, and occasionally was devoted to protecting, which was regarded as profoundly immoral and wicked, or divine and as a god. There were many forms of myths about the Grifon, as there were several forms and varied for it. This study will highlight the significance and 
symbolism of Grifon in ancient Egypt until the Greco-Roman Periods. The methodology of this study will be addressed through discussion of the notable aspects of the extent of effect of Grifon character through texts and scenes, and this will be through an analytical study on the significance, manifestations and symbolism of Grifon. The objectives of this study will be revealed through investigation, discussion and analysis which could be detected through detailed interrogation of the elements and structure of the content of this study, particularly as a basis for explaining the content and significance through the discussion and interpretation, all of which will be clear through the methodology, structure and content of this study.

\section{Griffin in different Iconographies and Hieroglyphic Sources}

The Grifon is one of the hybrid or compound mythological creatures. Its name has been derived from the Greek verb Greiffon which means "amazes- freaks - scares", and it should be noted that the name of the perpetrator of these acts is "amazingterrifying- scary", a linguistic reference to a term used as a characteristic of this mythical organism or animal called Griffin( Leibovitch,1942-45).The Grifon is in the form of a mythological creature compounded with the head of a falcon and the body of a lion and two wings, and these accessories or features give this object extraordinary abilities. The falcon's head has the ability to look high at the sky and could fly in an inverted position, it is believed that the falcon flies until it is almost close to the sun and that's why $\mathrm{Hr}$ is called "towering, high, or shaved", the wings also enable him to fly high (Meltzer,2002; Wilkinson, 2003). The raucous and dominant animals in the desert (Lurker,1978; Wilkinson, 2003).That's why this superstitious organism, Grifon, had the potential to distinguish it from other creatures. It is also one of the main reasons to be known in Greco-Roman periods as "amazing, terrifying, or frightening", perhaps this is due to his great abilities in throwing panic and fear into the hearts of enemies. It is important to note that that there is sometimes a confusion between the sphinx and the winged lion, Grifon , which is a winged lion with a hawk's head, not a lion with a human head, another type of the Grifon is the winged lion with a human head. The Grifon is mentioned in ancient Egyptian sources as $\int_{s f r}$, expressing the name of this mythical organism, a linguistic vocabulary meaning "incendiary"( Goldman,1960), it is mentioned in ancient Egyptian sources including in the inscriptions of the northern wall in the tomb of "Baqt III", which bears number 15 in the area of Beni Hassan, dating back to the eleventh dynasty, where that name is believed to have a clear 
The Significance and Symbolism of Grifon in Ancient Egypt till the GrecoRoman Periods

connection to the sun, which indicates the flame coming out of the animal's hollow ( Goldman,1960)(Fig.1).

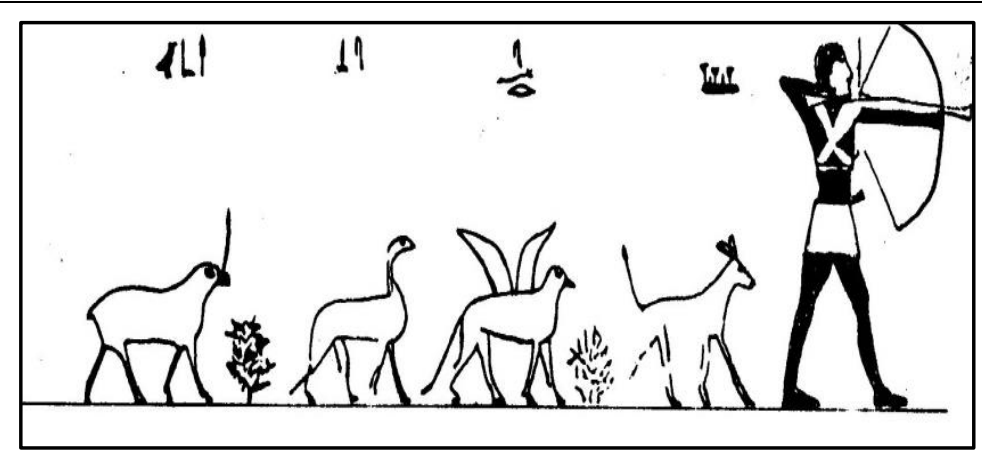

(Fig.1): Some animals include the Grifon and their names registered in the tomb of "Baqet" in Beni Hassan. After: (Griffith, 1895).

The ancient Egyptian sources during the Middle Kingdom mentioned another name as $(s) g r t r n . f$, which expresses a linguistic composition indicating the meaning of "silent by its name", referring to that it is over-fooling the enemies, this name occurred in the inscriptions of the northern wall of the hall of the tomb of "Khiti" bearing number 17 in the area of Beni Hassan, which dates back to the eleventh dynasty(Montet,1911)(Fig. 2).

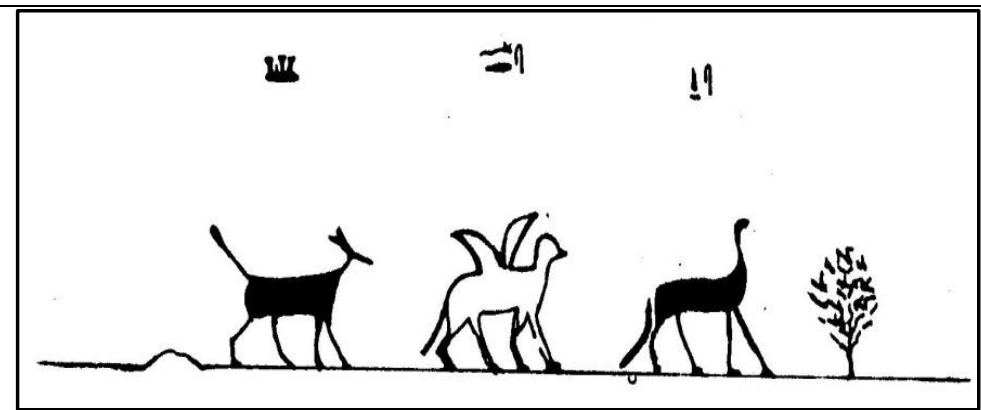

(Fig.2): Animals and their names registered in the tomb of "Khiti" in Bani Hassan.

After: (Griffith, 1895).

During the twelfth dynasty, the ancient Egyptian sources mentioned another name that was in the following writing form $\square$ tštš, which means "terminator", or "ripper" as a sign of the destruction and dismemberment of enemy parts, where that name is existed in the inscriptions of the exterior kiosk in the tomb of "Aha-Nakht", 
which bears number 5 in Al-Barsha archaeological area, dating back to the $12^{\text {th }}$ dynasty (Griffith,1895;Newberry, 1895)(Fig. 3).

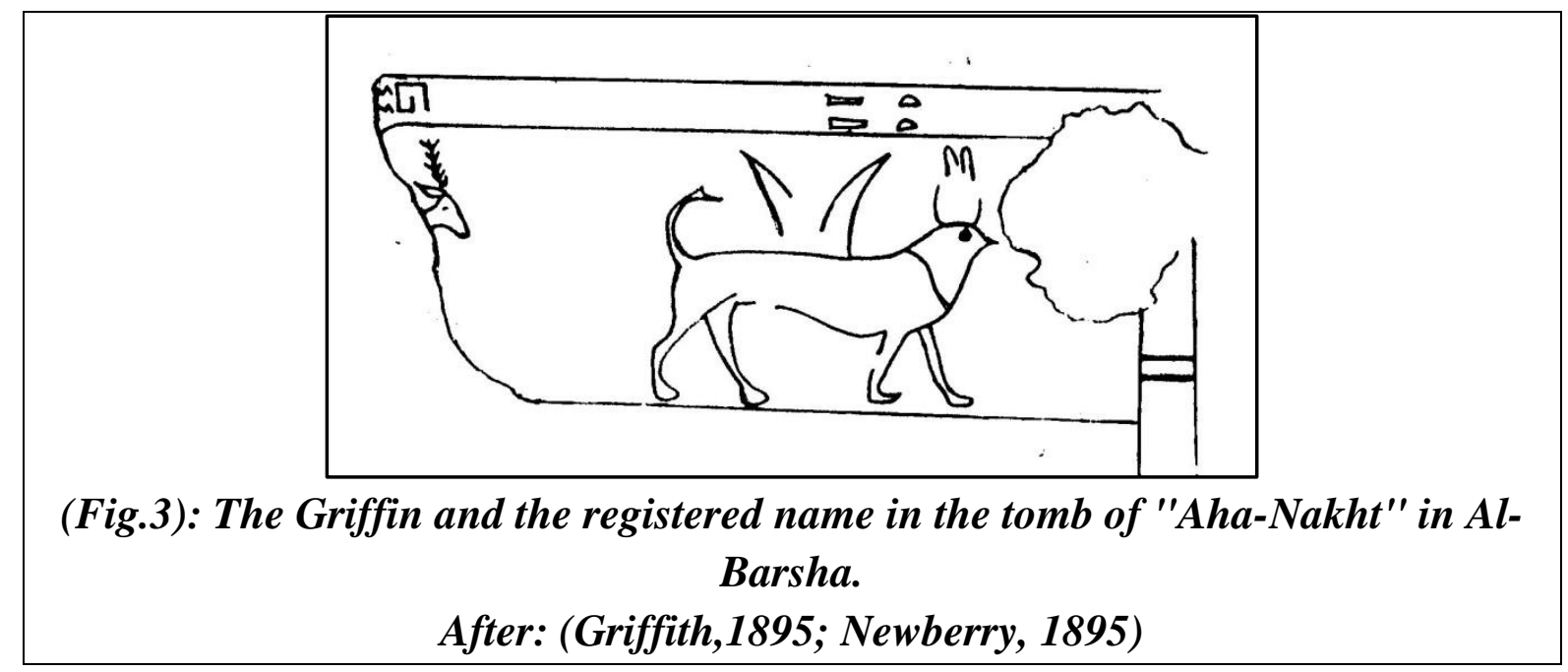

The ancient Egyptian sources during the New Kingdom is mentioned another name for that mythical object, where it was mentioned in the following writing form

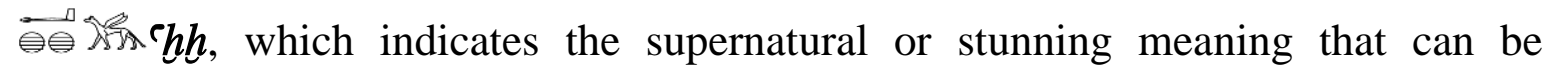
translated as "Grifon " as an expression of the power of the kings of Egypt (Wb. 1, 225). The name can be interpreted as "fast-moving or sudden for enemies or stalkers of enemies (Goldman,1960; Leibovitch, 1943). As for the longing of the linguistic

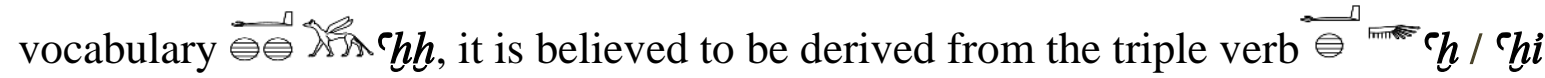
meaning "fly high"( Badawi\& Kees, 1958), as also the writing form is also reacted to $-c h$ / $h i$, which can therefore be translated in the sense of "shaver or towering"( Leibovitch,1943). The New Kingdom sources mentioned another name that was in the following writing form 4 imn, in the sense of "hidden" as an expression of the name of the Grifon, this was mentioned on a small statue of Taiba dating back to the New Kingdom, which is represented as a lion with the head of a falcon crowned with the disc of the sun and the recital of the god Amun, who was stepping enemies with his feet ( Leibovitch,1944). The king Ramses II described himself in the texts of the Battle of Kadesh as follows;

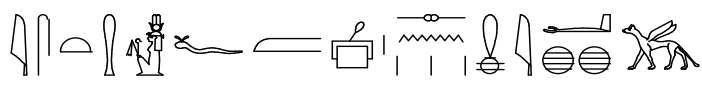

$$
\begin{aligned}
& \text { ist hom.f m-s3.sn mi chh }
\end{aligned}
$$

"His Majesty follows them like a marvelous /Grifon "( Kuentz,1928; Kitchen,1969). 


\section{The Significance and Symbolism of Grifon in Ancient Egypt till the Greco- Roman Periods}

The texts of the King Ramses II referred to the Grifon sought by describing himself as a lion flying like a hawk as follows;

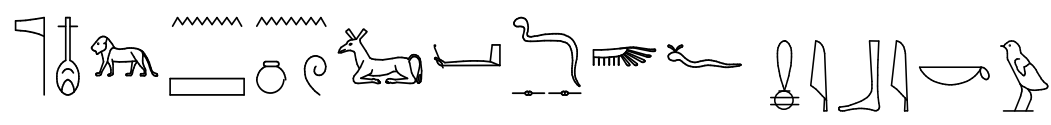

nțr nfr m3i nšnw dss.f mi bik

"He is the good God, the juicy lion, who flies like a hawk" (Kitchen,1969).

The texts of the complex temple of King Ramses II and the temple of Ramses III at Medinet Habu described the king as follows;

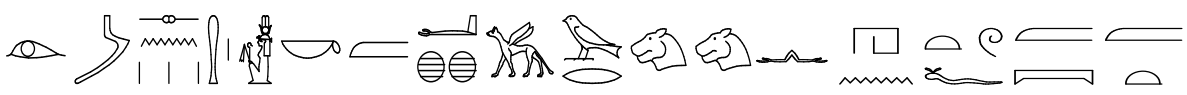

m33.sn hm.k $m$ Thh wr phty $n$ hn.tw.f $m p t m$ t3

"They see Your Majesty as the super/Grifon, the great power, which no one stops in heaven or in the earth"(Kitchen,1969).

\section{Forms and Manifestations of the Grifon in Ancient Egyptian Sources}

There were five forms and manifestations of the Grifon representations, which were mentioned in ancient Egyptian sources; the first form was represented by a bird's head that simplified its wings on its body, the second shape represented by the publisher of its wings, and the third form was represented by a human head spreading its wings, the fourth form is represented by the publisher of its wings to the back cross, and the fifth body represents it as an animal with a human head with the disappearance of the shape of the bird, which is called the sphinx (Barta,1974). It should be noted that this classification and division was based on the appearance or shape of the wings and head, but the researcher prefers to use another division and classification as follows;

- The First: the Sphinx as a human head.

- The Second: the winged lion with a falcon's head. 
- The Third: the winged lion with a human head, which also includes the female sphinx winged.

It should be noted that the Grifon played a dual role in ancient Egyptian beliefs as well as in the beliefs of the ancient Near East, where the Grifon sometimes played good or positive role, and so does the role of evil at other times. For example, the Grifon had a peaceful entity and nature in Syria (Crowfoot \& Davies,1941), where it is noted that the lion's head has emerged early in the west Asian regions, which had a close relationship with the sacred tree, as well as it was an assistant to the Kings in the wars and protector of them, it also fought monsters and enemies and took revenge on them, and it also played an auxiliary role in attracting or dragging god carts at times, as well as swallowing enemies of humans and animals, the Grifon was used as a decorative pillar, and the sacred tree was decorated with it (Goldman,1960). There were more graceful and beautiful bodies and appearances for the Grifon, where it was appeared in Crete which is the largest and most densely populated Greek islands, and then those appearances and bodies moved to Syria, and it is believed that more precise bodies and forms prevailed in Iraq, taking into account that the land of ancient Iraq was one of the first civilizations that created such superstitious beings (Crowfoot \& Davies,1941). The scenes and texts found in the cities of West Asia indicate that this mythical object was closely linked to religious symbols and connotations associated with solar beliefs, it was attracting the Lord of the Sun at times, and it also notes that the lion's body through which the Grifon sits has been unified and merged with the Lord of the Sun (Goldman,1960).

According to archaeological sources, the force of the Grifon corps served as a powerful source of protection and revenge against enemies and culprits, where it appeared in the form of entities and animals described by force such as lion, falcon and snakes, so it was thought to be considered one of the most powerful beings and entities. Hence the kings were represented in the form of the Grifon, which sets the enemies under his feet, where the texts glorified the king in that body, describing him as the force of all powers (Zakia, 1987). The Grifon is one of the superstitious animals mentioned in ancient Egyptian sources and archaeological evidence as a inhabitant of the desert, among the mentioned fierce desert animals, and the sources mentioned it as "demons", it was mentioned in the magical texts of the Middle Kingdom as it set foot and was also an anti-predator fighter, as well as was one of the protective entities of the deceased and was therefore photographed next to him, the sources described it as representing destiny and fate as it embodied the inevitable death, as well as one of the beings concerned with caring for the weak 
and taking revenge on them from their enemies(Bonnet,1952). The Grifon was represented in the form of a lion or a cheetah with a falcon's head, which indicated the extent of its connection and its relationship to the sun worship, this is illustrated by the name of the Sphinx of King Khafre in Giza $H r-m-3 h t$, as a sign of its association with the solar horizon in ancient Egyptian beliefs (Leibovitch,1943). It should be noted that one of the earliest examples of the Grifon in the form of a winged lion with a falcon's head has appeared on a palette made of schist that dates back to the pre-dynastic period, which was found in Hierakonpolis, also known as Al-Kom Al-Ahmar (Nekhen) in the third territory of the province of Aswan, which is preserved in the British Museum, and it is represented as a bull in the midst of various animals, where the animals look like are tied to a long rope (Hassan,1953; Quibell,1902). There is no text signal on the palette, but the wings are represented in a straight line, it is believed that was the first representation of the Grifon in the archaeological evidence of ancient Egypt (Leibovitch,1942) (Fig.4).

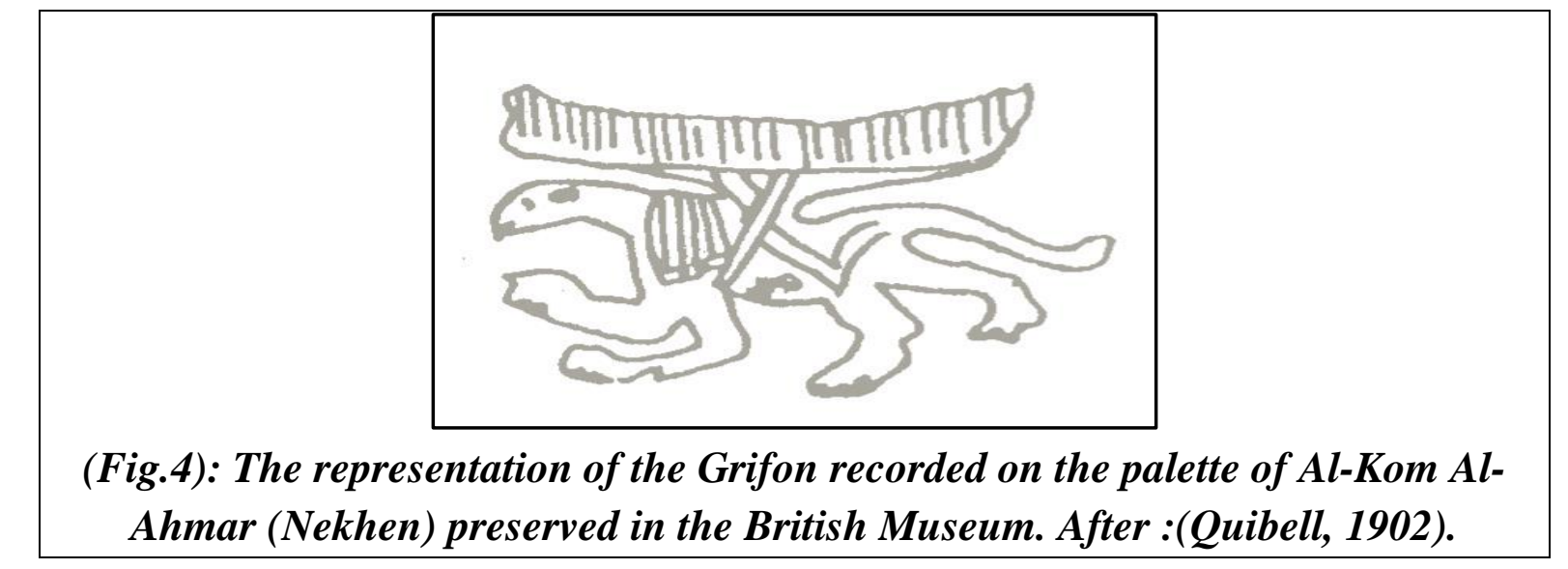

The Grifon was also represented on the knife of Jabal al-Taref, north of Naga Hammadi, a gold-plated knife dating back to the time of Naqada II, which is preserved in the Egyptian Museum of Cairo, where the Grifon spreading their wings among other animals such as lions and leopards chasing deer in the desert(Capart,1904; Quibell,1905)(Fig.5, 6). 


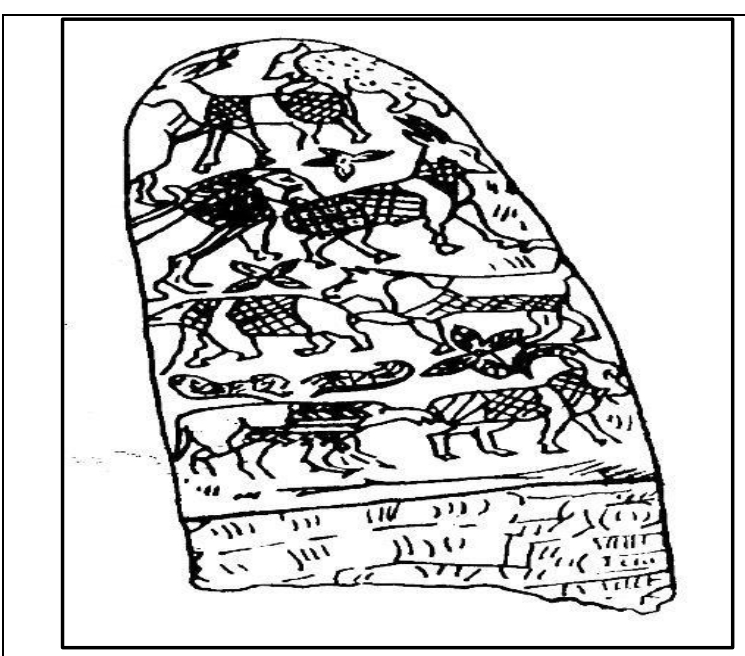

(Fig.5): Animals recorded on the handle of the knife of Jabal Al-Taref preserved in the Egyptian Museum.

\section{After: (Quibell, 1905).}

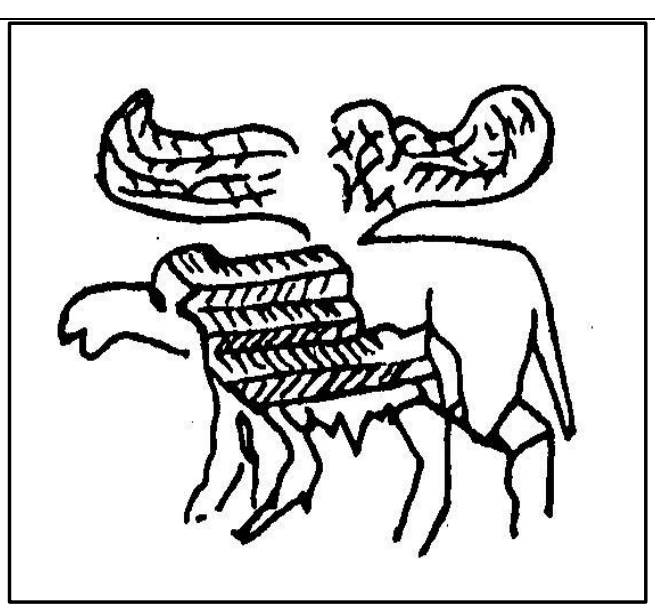

(Figure 6): Details of animals recorded on the handle of the knife of Jabal Al-

Taref - Egyptian Museum. After: (Quibell, 1905).

It should be noted that a limestone mascot has been found and is preserved in the British Museum, which dates back to the age of Naqada II, and the Grifon was represented on that mascot in a simple, blurred shape, its torso was surrounded by what looked like a strip of gold (Petrie,1914). It is believed that the representation of the Grifon at the time of the pre-dynastic period had no symbolic meaning, but just a sequence or just a stage to represent this legendary animal. In other words, they're just the beginnings of such creatures created and hybridized, which then continued through the scenes and texts (Hassan, 1953). In the inscriptions of the Temple of Sahura from the $5^{\text {th }}$ dynasty of Abusir, the remains of a view representing the Grifon was found as winged as a hawk's head, it had a half-circlehigh tail, and it had two wings(Budge,1977)(Fig.7).

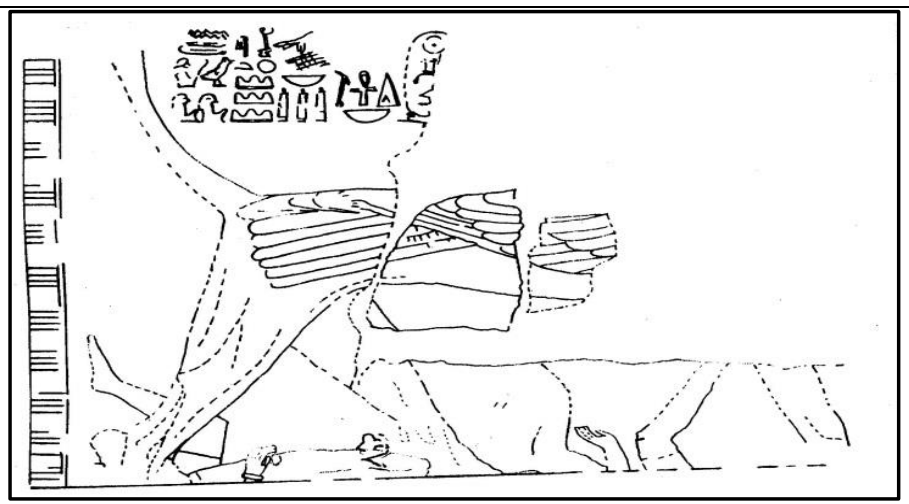

(Fig.7): Remnants of a scene representing the Grifon with the head of a hawk from the Temple of Sahura. After: (Quibell, 1907). 


\section{The Significance and Symbolism of Grifon in Ancient Egypt till the Greco-}

Roman Periods

Although there is no head in the view, it can be said that it has a falcon's head compared to similarly appeared in the Temple of "Bebi II" from the age of the sixth dynasty in Saqqara, it notes the direction, details and shape of the entire wings(Jequier, 1940), (Fig.8).

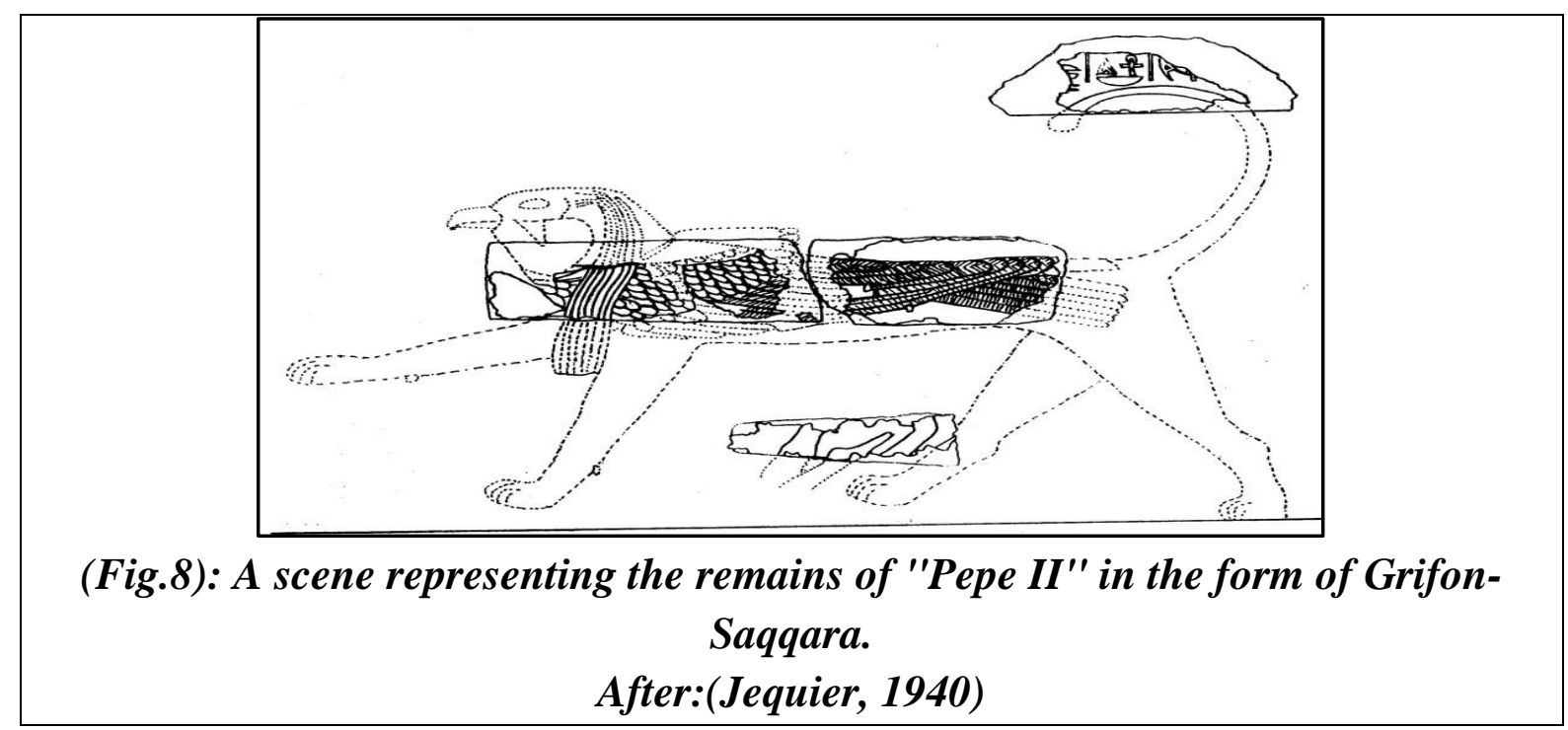

It should be noted that there is an accompanying text of the view referring to the King and describing him as such as; $\underline{d} h w t y$ in the process of suppressing, disciplining and eliminating enemies stating the following;

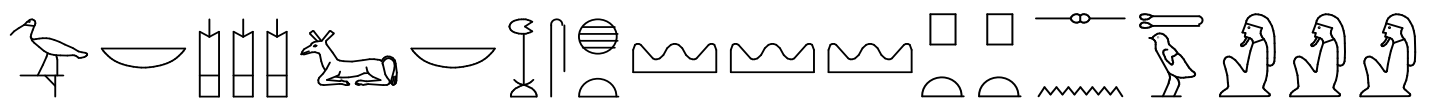

Dḥty nb iwntyw nb h3swt ptpt sntyw

"Thot, the lord of Iontyw (inhabitants of the Eastern desert), and the lord of the foreign countries, who sets foot in the Berbers"( Leibovitch,1943).

The Grifon was also represented as a winged lion with a hawk's head in the inscriptions of the north and south walls of the Temple of Bebe II in Saqqara ( Leibovitch,1943). The best is the view on the southern wall, which embodies the king stepping on enemies with his feet, it was handled the scene and made an imaginary redraw of it so it could be traced and studied (Leibovitch,1943). It seems that this composite, created or hybrid object, made up of a winged lion with the head of a falcon (Grifon ), embodied the body and appearance of the king, it is also confirmed the relationship between the king on the one hand, and the God Horus on 
the other, which is undoubtedly an ongoing and existing relationship, of course, through the ancient Egyptian civilization, which was not limited to the age of the Old Kingdom only (Zakia, 1987). The representation of the Grifon continued in the scenery during the Middle Kingdom, among them is a view of the northern wall of the hall of the cemetery "Baqet III", which bears number 15 in the area of Bani Hassan, which dates back to the eleventh dynasty(Fig.1), where the body of a winged lion appeared with the head of a falcon and a live tail, and there is a name

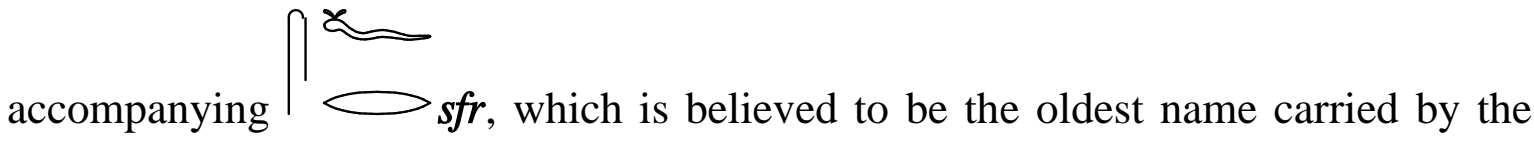
Grifon (Newberry,1893). It was represented among the various animals of the desert, and there is a pig in front of it associated with "Setekh", with a name written

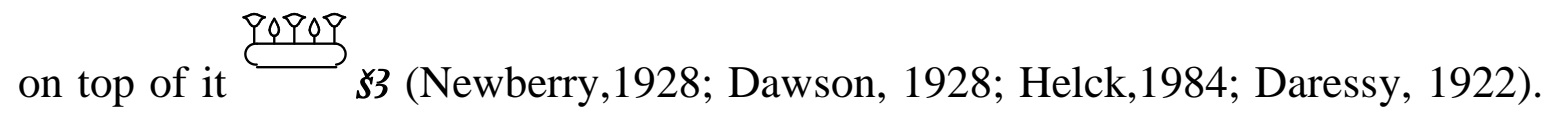
The ancient Egyptian named the pig $\$ 3 / \$ 3 i$, and was responding in the following writing form there was another legendary animal, which is likely to be very similar to one of the

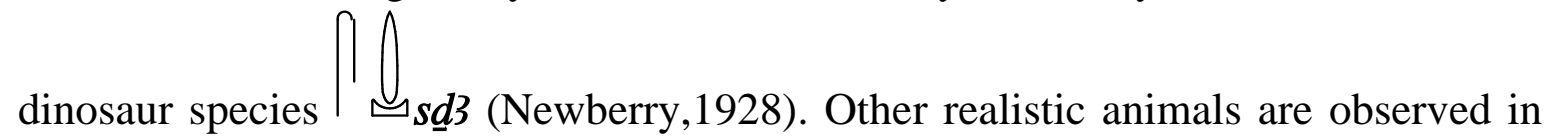
addition to the aforementioned animals such as lion, elephant and deer(Newberry,1893). There are two other views representing the Grifon in the inscriptions of the hall of the tomb of "Khiti" No. 17 in the area of Bani Hassan on the east bank of the Nile, which belonged to the $16^{\text {th }}$ region of middle Egypt dating back to the $11^{\text {th }}$ dynasty (fig.2), the first view is represented on the northern wall by its name ${ }^{2} \bigodot_{s f r}$, and this time in front of it the animal $s_{s \underline{d} 3 \text {, on the behind }}$ there is the animal of "Setekh", known as $\$ 3$ among other representations of hunting animals, while the second view was recorded on the south wall of the tomb hall, which is one of the distinct views, because this time it represents the Grifon in the form of an animal, which may be represented in the form of a female lion/lioness because there are more than one breast for the animal, which appears to be winged with a falcon's head, and wore a broken eyelid around its neck, and it has its wings in front of the deceased and its wife. Below the view is observed the presence of a hound in a situation similar to that of a Grifon, Therefore, it is believed that the role of the Grifon here facilitates and overcomes the difficulties surrounding the fishing process, and was undermined around its neck like a dog because their role is not so different from the other(Newberry,1893).The presence of the name of the Grifon is 


\section{The Significance and Symbolism of Grifon in Ancient Egypt till the Greco-}

Roman Periods

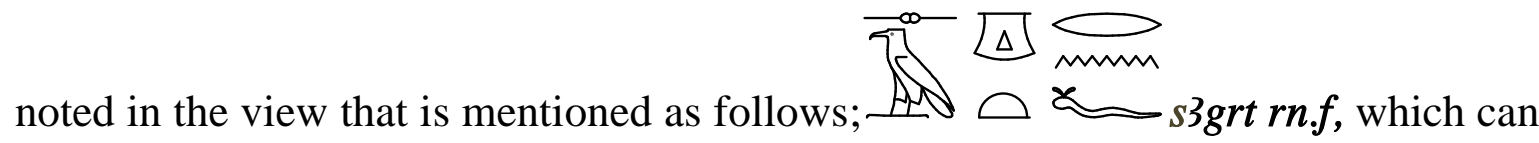
be translated in the sense of "silent named"( Montet,1911; Leibovitch,1943) (Figs.9,10).

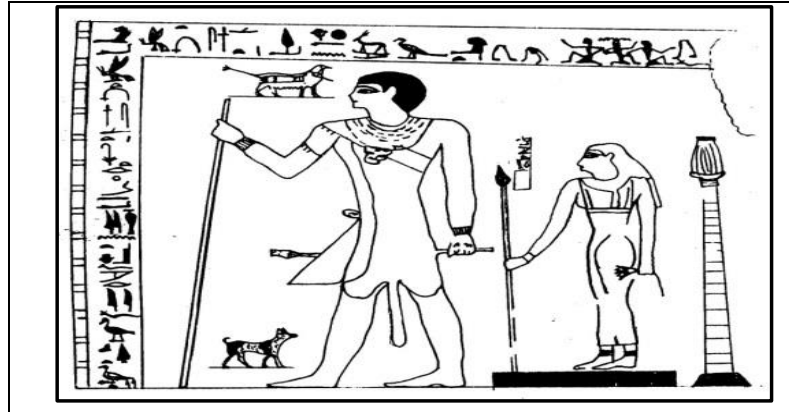

(Fig.9): A scene representing "Kheti" and his wife accompanied by Grifon and a dog. After: (Newberry,1893).

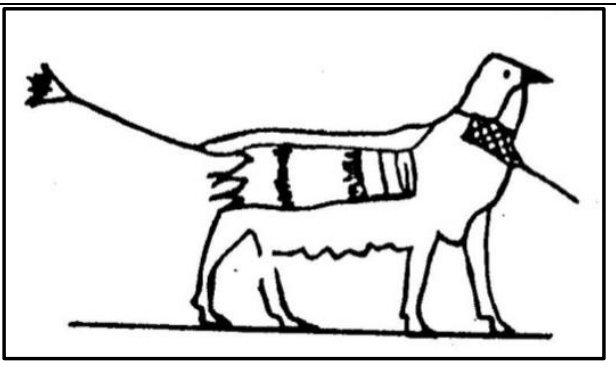

(Fig.10): Detail of the representation of the Grifon with a falcon's head, detailed from the previous form. After: (Newberry,1893).

The Grifon is also appeared in the views of the northern wall of the Kiosk of The Aha-Nakht tomb No. 5 in Al-Barsha region, which followed the $15^{\text {th }}$ nome of present-day Minya and dated the twelfth dynasty (Form 3), and it appears in the form of a winged lion with a falcon's head named $\square \square t s ̌ s$, , in the sense of $X$

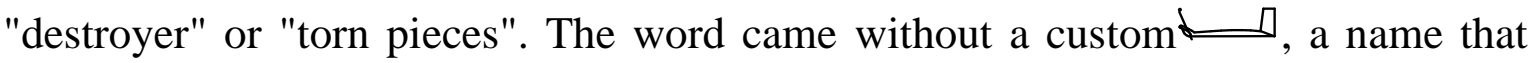
later spread in the sources of the New Kingdom (Griffith \& Newberry,1893-95). The Grifon was also represented twice left and right on a waistcoat dating back to the reign of King Senusret III from the twelfth dynasty, where the representation was on the right and left of the king's name to give him protection, strength and fortitude (de Morgan, 1895). It became one of the favorite themes on the thrones of kings and their war wheels during the New kingdom, which is believed to have been represented on the king's throne to protect him from enemies, as well as to give him stability and strength. The Grifon appeared on the King Tut-ankh-amun's furniture box (Leibovitch,1942). It is believed that the word $\rightleftharpoons$ mntw referring to the name of the war god Montu was also referring to one of the names 
of the Grifon, it was contained on a wooden panel dated the reign of King Amenhotep II (Hassan, 1953), and this confirms that the same name was once again represented by the highest axe of the King Ahmose I from the beginning of the eighteenth dynasty (Fig.11).

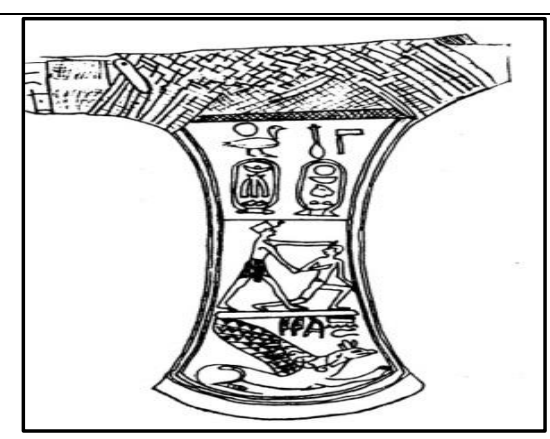

(Fig.11): The head axe of the King Ahmose I. After: (Leibovitch,1942)

There are some titles represented at the top of the axe, then a view represented by the blue crown, and a captive was captured with his hands, while under the axe the legendary Grifon appeared with his wings shrieked up, at its head is

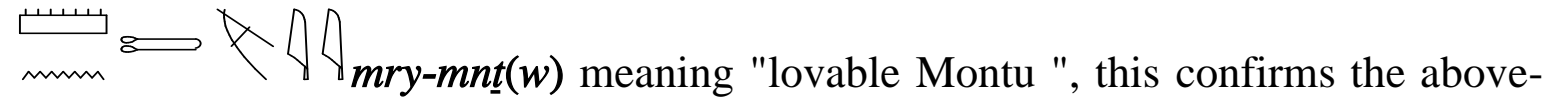
mentioned view that he was gaining the military tool likewise the power of oppression and effectiveness (Capart,1957). The Grifon was represented in the form of a lion with the head of a female eagle/female punishment, not a lion with a falcon's head, and it appeared on the head axe of the King Ahmose I from the beginning of the $18^{\text {th }}$ dynasty (Leibovitch,1942). It should be noted that the Grifon with the head of the eagle (female punishment) was not common in Egypt probably before the eighteenth dynasty (Leibovitch,1942)( (Fig.12).

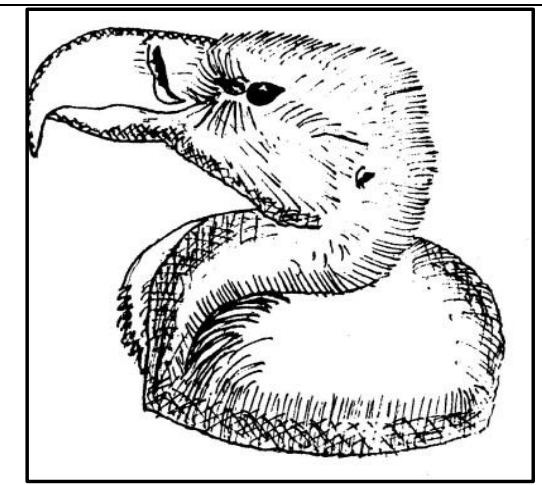

(Fig.12): Detail of the female eagle bird (female punishment) recorded on top of the axe of the King Ahmose I. After: (Leibovitch,1942) 


\section{The Significance and Symbolism of Grifon in Ancient Egypt till the Greco- Roman Periods}

The Grifon was represented with the head of the eagle (female punishment) sitting and it was a decorative element represented on a gold bracelet preserved in the Louvre Museum, it is likely to date back to the $18^{\text {th }}$ dynasty (Leibovitch,1942), which was dated based on the shape of the plant decorations that appeared on it. It is believed that the representation of the Grifon on this bracelet was for the purpose of giving the fist to those who wear it, as well as force and bashing (Leibovitch,1942)(Fig. 13).

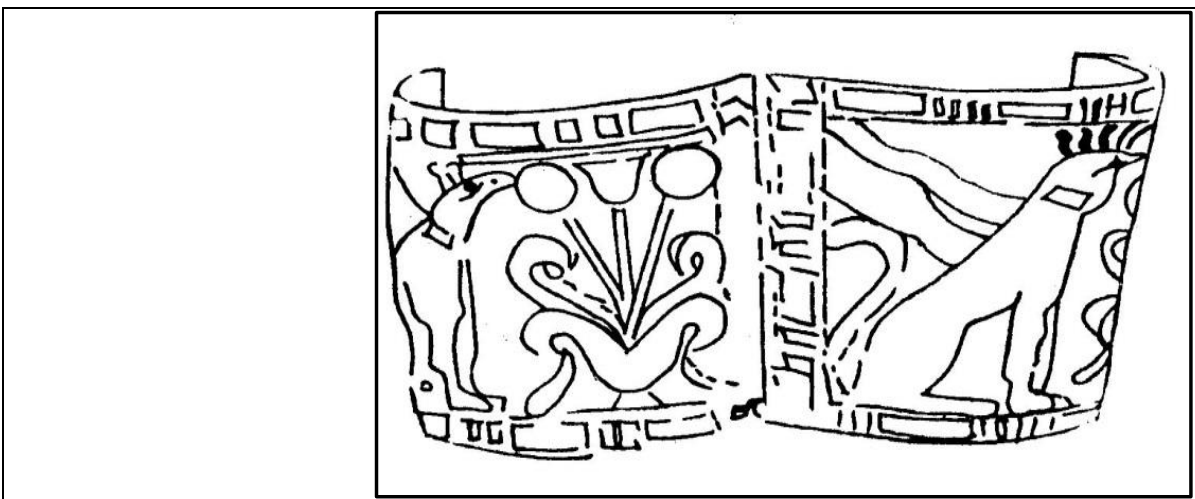

(Fig.13): The golden bracelet represented by the Grifon - Louvre Museum. After: (Leibovitch,1942)

It should be noted that sometimes the winged lion's head was replaced by the head of a falcon or eagle by the head of a long-eared jackal, and that was consistent with the description of "Pliny" (Leibovitch,1942) . This creature, created from a winged lion with the head of a jackal animal, was mentioned on a piece of cloth found inside a box of the king Tutankhamun's possessions, which was number 367 and is preserved in the Egyptian Museum in Cairo, The Grifon was represented in the hunting scenes, and there is another view on the right representing a winged lion female with a human head, on the left was a view of two Grifon facing each other, much like a winged jackal(Crowfoot\& Davies, 1991) (Fig.14) . 


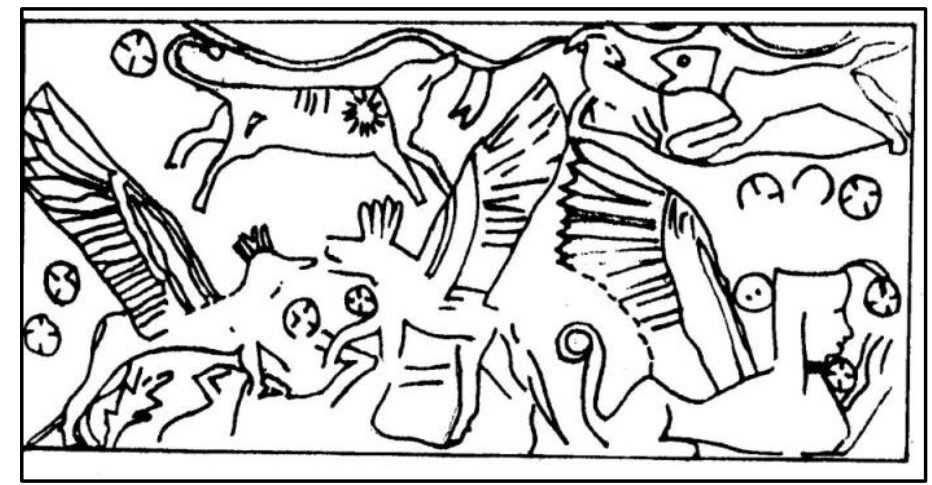

(Fig.14): A piece of clothing of Tutankhamun's collections preserved in the Egyptian Museum- Cairo. After:(Crowfoot\& Davies,1991)

It is believed that this interpretation of the Grifon seems acceptable because it is contained in the Pyramids texts, which supports the fact that the king was represented in the form of a falcon with the head of a jackal, where it is mentioned in the Pyramids texts showing the desire of the deceased king to become a hybrid being mounted from the front of a jackal animal rear of a falcon, and it seems that the king in that body was the embodiment of the Grifon and the power of his oppression(Sethe, Pyr. 865-b) . This last view can be compared to another one that appeared on a silver pot preserved in the Egyptian Museum in Cairo, which found in Tell-Basta in Zagazig the capital of the governorate of Sharqia, and was among the possessions of the deceased Atum-M-Tanb, a historian of the nineteenth dynasty, the various hunting animals are represented at the top of the pot nozzle, and the far right shows the griffin in the form of a winged lion with a bird's head (not Jackal)( Simpson, 1959; Edgar, 1925). There is an amulet made of red jade, preserved in the British Museum and dated to the reign of King Ramses II, has been found, The mascot took the form of a winged lion with a hawk's head, and was registered on the base of the mascot the name of the king in addition to the name of the god "Montu" the lord of war (Petrie,1914), the follicles were also represented in a pottery pots dated to the New Kingdom, where it was represented by four strands of hair behind his head (Leibovitch,1942). As well as, there is an amulet found in the form of a Scarab preserved in the Egyptian Museum in Cairo and dated to the New Kingdom and appeared on it two Grifon animals with their feet a wild deer, their appearance seem to reflect victory, as they appear to flutter their wings as a symbolic indication of the power of oppression and victory, it is believed that this 


\section{The Significance and Symbolism of Grifon in Ancient Egypt till the Greco-}

Roman Periods

view of the mascot was referring to a symbolic struggle between the Grifon on the one hand and the enemies of the God "Ra" on the other, which is the traditional theme that usually accompanies fishing scenes. It should be noted that this mascot had several purposes, which carries to provide the protection, freshness and renewal represented by the insect of the Scarab, in addition to some of the religious symbolic meanings and connotations that have been represented, the Grifon was the main theme, the embodiment of the idea of eliminating the evil represented by the enemies of the God "Ra" (Leibovitch,1942). There are many Scarabs of the New Kingdom that represent the neighborhoods of the Grifon, some of which represent and have extended both wings (Leibovitch,1942), sometimes sit on a red crown or a white crown (Leibovitch, 1942), and sometimes show up with a head that looks like the bird of "Rekhit" (Leibovitch, 1942). It can be said that the Grifon played a role that was not overlooked in ancient Egyptian beliefs; a gesture that helps the king in wars and suppresses enemies, or protects him, it is believed that it is a purely Egyptian being who is not from Egypt from any foreign country, and that it has roots dating back to the pre-dynastic period, where it represented the prayer of the British Museum as mentioned before, and perhaps the Asians moved it from Egypt, in addition to the many symbolic meanings they conveyed (Goldman,1960), where the Egyptian Grifon of this kind is similar to one of the two pictures of the Iraqi Grifon to a large extent (Black \& Green,1992) (Fig.15).

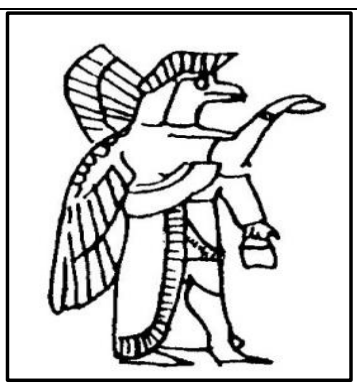

(Fig. 15): The Iraqi Grifon in the form of a winged lion with a hawk's head. After:(Black \& Green,1992)

As for the second appearance of the Iraqi Grifon is not common in the ancient Egyptian art, and this was what appeared in the form of a winged humanity with a hawk's head (Black \& Green,1992) (Fig.16). 


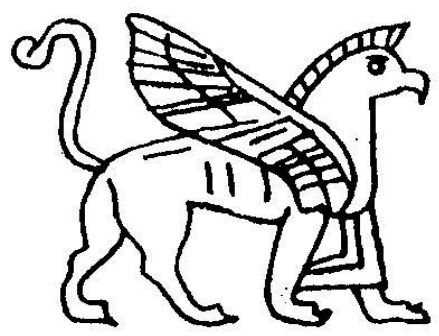

(Fig. 16): The Iraqi Grifon in the form of a human winged with a hawk's head. After:(Black \& Green,1992).

It is also noted that the apparent similarity between the Egyptian Grifon and the Ethiopian counterpart was represented the epilepsy of the king's enemies (Lepsius,1894), there are a number of Ethiopian ornaments on which the Grifon is used as a decorative element, including a ring preserved at the Berlin Museum(Lepsius,1894). Accordingly, the Egyptian Grifon found the way to the ancient Iraqi art and to Ethiopia art in the south, which embodied an auxiliary, evilchasing object subject to enemies, but it did not reach the ranks of the gods (Lepsius, 1894).

During the Greco-Roman periods, the Grifon was represented by the Idol Dionysus, a passenger of a two-wheeled vehicle dragged by three different animals in red on a black floor (http://www.theoi.com/Gallery/K12.8.html) (Fig.17). Among these animals is the Grifon, from which only parts of the front half appear and are based on the hind feet that appear under the bull's abdomen, it is a composite animal from a lion's body, as it appears from its front feet, which ends with claws and a hawk's head protruding from the middle of its back to the top of two wings deployed back.

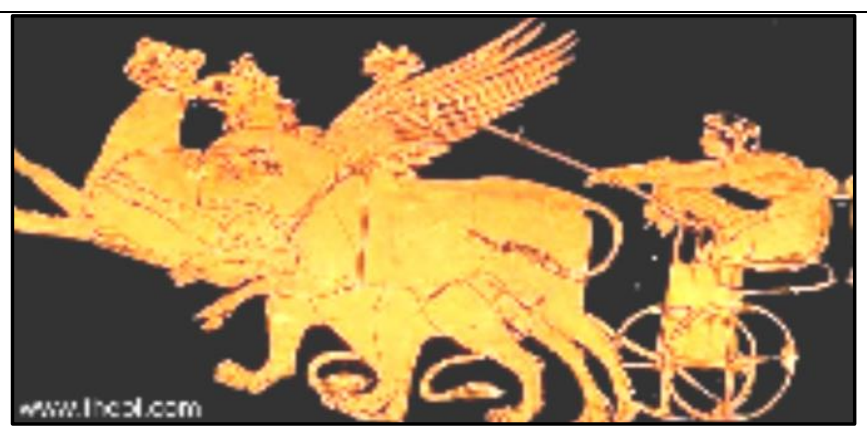

(Fig.17) The God Dionysus, a passenger in a vehicle dragged by three animals, including the Grifon. After: (http://www.theoi.com/Gallery/K12.8.html, accessed date 18/7/2020) 


\section{The Significance and Symbolism of Grifon in Ancient Egypt till the Greco- Roman Periods}

The god Apollo is also used the winged Grifon as a means of moving into the Greek legend, a red-style photographer on the black floor appears on a Kylix pottery vessel (http://www.theoi.com/Gallery/M29.2.html). (Fig.18), the method of riding indicates that the Grifon is flying high.

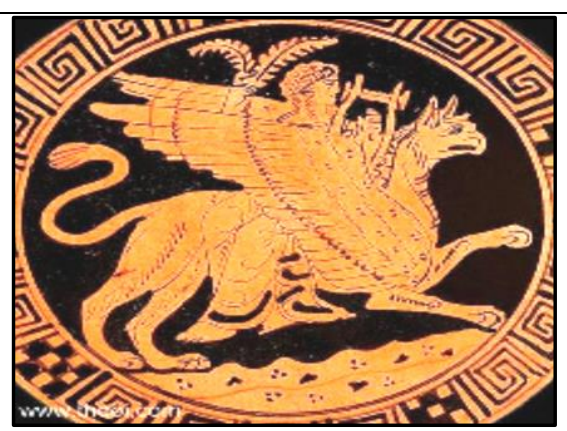

(Fig.18) The winged Grifon used by the god Apollo as a means of moving on to the Greek legend. After: (http://www.theoi.com/Gallery/M29.2.html, accessed date 18/7/2020)

\section{Conclusion}

This study is focused and examined the ancient Egyptian iconography and texts of the mythological creature and the artistic form, which known as Grifon, Griffin, Griffon and Gryphon, and this was through glimpses of appearance in Egyptian sources since the earliest times till the Greco-Roman periods. This study was highlighted through the religious iconography of the Grifon and the distinctive relationship of the Grifon with some other gods such as; Re and Horus Behdety, as well as and the relationship of the Grifon with the Ka of the King. It should be noted that the frequent manifestations of the Grifon provide three main forms, which may be distinguished as follows; the human headed Sphinx, the winged lion with a falcon head, and the human headed winged lion, which also includes the female sphinx winged. It can be said that the Grifon or the so-called Gryphon, Grifon, Griffin, Griffon was one of the oldest and most composite and mixed creatures or hybrid animals in the civilizations of ancient Egypt and ancient Near East, where there were many shapes and various characteristics of the Grifon that emerged in many texts and scenes. Sometimes the Grifon was violent and predator creature and was regarded as profoundly immoral and wicked. Occasionally, the Grifon was also a creature devoted or dedicated to protection and was regarded as a god or a divine creature. It was noticed that there were many forms of myths revolving around the Grifon, where there were several shapes and diverse manifestations of the Grifon. This study is highlighted the significance and symbolism of the Grifon in ancient 
Egypt till the Greco-Roman Periods, where the methodology of this study was addressed through discussion of the notable aspects of the extent of effect of the Grifon creature through texts and scenes. The aims of this study are revealed through investigation, discussion and analysis which detected through detailed interrogation of the elements and structure of the content of this study, particularly as a basis for explaining the content and significance through the discussion and interpretation, all of which became apparent through the methodology, structure and content of this study.

\section{Results}

- The Grifon is one of the hybrid or compound mythological creatures. Its name has been derived from the Greek verb Greiffon which means "amazes- freaks scares", and it should be noted that the name of the perpetrator of these acts is "amazing- terrifying- scary", a linguistic reference to a term used as a characteristic of this mythical organism or animal called Griffin.

- The Grifon was in the form of a mythological creature compounded with the head of a falcon and the body of a lion and two wings, and these accessories or features give this object extraordinary ability. The falcon's head has the ability to look high at the sky and could fly in an inverted position, it is believed that the falcon flies until it is almost close to the sun and that's why $H \mathrm{r}$ is called "towering, high, or shaved", the wings also enable him to fly high.

- The earliest examples of the Grifon in the form of a winged lion with a falcon's head has appeared on a palette made of schist that dates back to the pre-dynastic period, which was found in Hierakonpolis, also known as Al-Kom Al-Ahmar (Nekhen) in the third territory of the province of Aswan, which is preserved in the British Museum, and it is represented as a bull in the midst of various animals, where the animals look like are tied to a long rope, but there is no text signal on the palette, however the wings are represented in a straight line, it is believed that was the first representation of the Grifon in the archaeological evidence of ancient Egypt.

- The Grifon was also represented on the knife of Jabal al-Taref, north of Naga Hammadi, a gold-plated knife dating back to the time of Naqada II, which is preserved in the Egyptian Museum of Cairo, where the Grifon was spreading their wings among other animals such as lions and leopards chasing deer in the desert.

- The Grifon was mentioned in the ancient Egyptian sources as "sfr", expressing the name of this mythical organism, a linguistic vocabulary meaning "incendiary", it was also mentioned in ancient Egyptian sources, including in the inscriptions of the northern wall in the tomb of "Baqt III", which bears number 15 in the area of Beni Hassan, dating back to the eleventh dynasty, where that name is believed to have a clear connection to the sun, which indicates the flame coming out of the animal's hollow. 


\section{The Significance and Symbolism of Grifon in Ancient Egypt till the Greco- Roman Periods}

- The ancient Egyptian sources during the Middle Kingdom mentioned another name as (s)grt $r n . f$, which expresses a linguistic composition indicating the meaning of "silent by its name", referring to that it is over-fooling the enemies, this name occurred in the inscriptions of the northern wall of the hall of the tomb of "Khiti" bearing number 17 in the area of Beni Hassan, which dates back to the eleventh dynasty.

- During the twelfth dynasty, the ancient Egyptian sources mentioned another name that was in the following writing form $t \breve{s t} t^{\zeta}$, which means "terminator", or "ripper" as a sign of the destruction and dismemberment of enemy parts, where that name is existed in the inscriptions of the exterior kiosk in the tomb of "Aha-Nakht", which bears number 5 in Al-Barsha archaeological area, dating back to the $12^{\text {th }}$ dynasty.

- The ancient Egyptian sources during the New Kingdom mentioned another name for that mythical object, where it was mentioned in the following writing form Chh, which indicates the supernatural or stunning meaning that can be translated as "Grifon " as an expression of the power of the kings of Egypt. The name can be interpreted as "fast-moving or sudden for enemies or stalkers of enemies.

- The King Ramses II described himself in the texts of the Battle of Kadesh as a marvelous /Grifon, as the King Ramses III described himself at the inscriptions of the temple of Medinet Habu as a lion flying like a hawk/ Grifon. Hence the Kings were represented in the form of the Grifon, which sets the enemies under his feet, where the texts glorified the king in that body, describing him as the force of all powers.

- The Grifon played a dual role in ancient Egyptian beliefs as well as in the beliefs of the ancient Near East, where the Grifon sometimes played good or positive role, and so does the role of evil at other times. For example, the Grifon had a peaceful entity and nature in Syria, where it is noted that the lion's head has emerged early in the west Asian regions, which had a close relationship with the sacred tree, as well as it was an assistant to the kings in the wars and protector of them, it also fought monsters and enemies and took revenge on them, and it also played an auxiliary role in attracting or dragging god carts at times, as well as swallowing the enemies of humans and animals, the Grifon was used as a decorative pillar, and the sacred tree was decorated with it.

- There were five forms and manifestations of the Grifon representations, which were mentioned in ancient Egyptian sources; the first form was represented by a bird's head that simplified its wings on its body, the second shape represented by the publisher of its wings, and the third form was represented by a human head spreading its wings, the fourth form is represented by the publisher of its wings to the back cross, and the fifth body represents it as an animal with a human head with the disappearance of the shape of the bird, which is called the sphinx. It should be noted that this classification and division was based on the appearance 
or shape of the wings and head, but the researcher prefers to use another division and classification as follows; the first was the Sphinx as a human head, the second was the winged lion with a falcon's head, and the third was the winged lion with a human head, which also included the female sphinx winged.

- There were more graceful and beautiful bodies and manifestations for the Grifon, where it was appeared in Crete which is the largest and most densely populated Greek islands, and then those appearances and bodies moved to Syria, and it is believed that more precise bodies and forms prevailed in Iraq, taking into account that the land of ancient Iraq was one of the first civilizations that created such superstitious beings. It should be noted that the scenes and texts found in the cities of West Asia indicate that this mythical object was closely linked to religious symbols and connotations associated with solar beliefs, it was attracting the Lord of the Sun at times, and it also notes that the lion's body through which the Grifon sits has been unified and merged with the Lord of the Sun.

- There were many Scarabs of the New Kingdom that represent the neighborhoods of the Grifon, some of which represent and have extended both wings, sometimes sit on a red crown or a white crown, and sometimes show up with a head that looks like the bird of "Rekhit". It can be said that the Grifon played a role that was not overlooked in ancient Egyptian beliefs; a gesture that helps the king in wars and suppresses enemies, or protects him, it is believed that it is a purely Egyptian being who is not from Egypt from any foreign country, and that it has roots dating back to the pre-dynastic period, where it represented the prayer of the British Museum as mentioned before, and perhaps the Asians moved it from Egypt, in addition to the many symbolic meanings they conveyed, where the Egyptian Grifon of this kind is similar to one of the two pictures of the Iraqi Grifon to a large extent.

- The second appearance of the Iraqi Grifon is not common in the ancient Egyptian art, and this was what appeared in the form of a winged humanity with a hawk's head. It was also noted that the apparent similarity between the Egyptian Grifon and the Ethiopian counterpart was represented the epilepsy of the king's enemies, there are a number of Ethiopian ornaments on which the Grifon is used as a decorative element, including a ring preserved at the Berlin Museum. Accordingly, the Egyptian Grifon found the way to the ancient Iraqi art and to Ethiopia art in the south, which embodied an auxiliary, evil-chasing object subject to enemies, but it did not reach the ranks of the gods.

- During the Greco-Roman periods, the Grifon was represented by the God Dionysus, a passenger of a two-wheeled vehicle dragged by three different animals in red on a black floor. Among these animals is the Grifon, from which only parts of the front half appear and are based on the hind feet that appear under the bull's abdomen, it is a composite animal from a lion's body, as it appears from its front feet, which ends with claws and a hawk's head protruding from the middle of its back to the top of two wings deployed back. 


\section{The Significance and Symbolism of Grifon in Ancient Egypt till the Greco- Roman Periods}

- The God Apollo was also used the winged Grifon as a mean of moving into the Greek legends, a red-style photographer on the black floor appears on a Kylix pottery vessel, the method of riding indicates that the Grifon is flying high.

\section{References:}

- Badawi, A., \& Kees, H.,(1958), Handwörterbuch der Ägyptischen Sprache, Kairo.

- Barta, W.,(1974), Der Grief, Journal of the Oriental Institute, Vol. 23, Baroda,p.336.

- Black, J., \& Green, A.,(1992),Gods, Demons and Symbols of Ancient Mesopotamia, London, pp.99ff.

- Bonnet, H.,(1952), Realexikon der ägyptischen Religion Geschichte, Berlin.

- Budge, W.,(1977), The Book of the Dead, Vol. 2, London.

- Capart, J.,(1904), Conference Sur la Prehistariqus Egyptien, Bruxelles.

- Capart, J.,(1957), Au pays du symbolisme, Chronique d'Egypte, Vol. 32, Issue 64, p. 220.

- Crowfoot, G., \& Davies De G.,(1941), The Tunic of Tut-Ankh-Amun, JEA 27, London,p.129.

- Daressy, M.G.,(1922), Casse - Tete Préhistorique de Bois de Gébelein, ASAE 22, pp.17-32.

- Dawson, W. R.,(1928), The Pig in Ancient Egypt : Commentary on two passage of Herodotus, Journal of the Royal Asiatic Society of Great Britain and Irelandin/JRAS 3, pp.597-608.

- de Morgan, J.,(1895), Fouilles a DAhchour, Vol. 1, Vienne.

- Edgar, C.,(1925), Engraved designs on a silver vase from Tell-Basta, ASAE 25, p. 257.

- Goldman, B.,(1960), The development of the lion-Griffen, AJA 64/4,p.328.

- Griffith, F. L., \& Newberry, P. E.,(1893-95), El-Bersheh, London, pp. 34f.

- Hannig, R., (2000),Großes Hand Wörterbuch, Ägyptische Deutsch, Die Sprache der Pharaonen, Mainz.

- Hassan, S.,(1953), The Great Sphinx and its Secrets, Cairo.

- Helck, W.,(1984), "Schwein", LÄ V, Cols.762-764.

- Jequier, G.,(1940), Les Monuments Funeraire de Pepi II, Vol. 3, Le Caire.

- Kitchen, K.,(1969), Ramesside Inscriptions, Vol.2/1, Oxford.

- Kuentz, Ch.,(1928), La Bataille de Qadech, MIFAO 55, Le Caire.

- Leibovitch, J. (1942). Quelques éléments de la décoration égyptienne sous le Nouvel Empire. Bull. de l'Inst. d'Égypte, 25, pp.282-283.

- Lepsius R.,(1894-59), Dabkmaeler au Aegypten Und Aethiopien, 12 Vol.10, Berlin. 
- Lurker, M.,(1987), Dictionary of Gods and Goddesses, Devils and Demons, Routledge Press, London.

- Meltzer, E.S.,(2002), "Horus". In: D. B. Redford (Ed.), The ancient gods speak: A guide to Egyptian religion, Oxford University Press, Oxford, p.164.

- Montet, P.,(1911), Notes Sur Les Tombeaux de Beni - Hassan, BIFAO 9,Le Caire,p.17f.

- Newberry, P. E.,(1893), Beni-Hassan, Vol. 2, London.

- Petrie, W. F.,(1914), Amulets, London.

- Quibell, J. E.,(1902), Hierakonpolis, Vol. 2, London.

- Quibell, M.,(1905), Archaic Objects, Vol. 1, Le Caire.

- Simpson, W. K.,(1959), The Vessels with Engraved designs, American Journal of Archaeology, Vol. 63, No. 1, p.32ff.

- Wilkinson, R.H.,(2003), The Complete Gods and Goddesses of Ancient Egypt, Thames \& Hudson Press, London.

- Zakia Zaki Jamal al-Din,(1987), The God Horus originated and his relationship with the monarchy from the dawn of history until the end of the old kingdom, manuscript of an unpublished $\mathrm{PhD}$ Letter, Faculty of archeology, Cairo University.

\section{Websites:}

- http://www.theoi.com/Gallery/K12.8.html, accessed date 18/7/2020)

- http://www.theoi.com/Gallery/M29.2.html, accessed date 18/7/2020) 